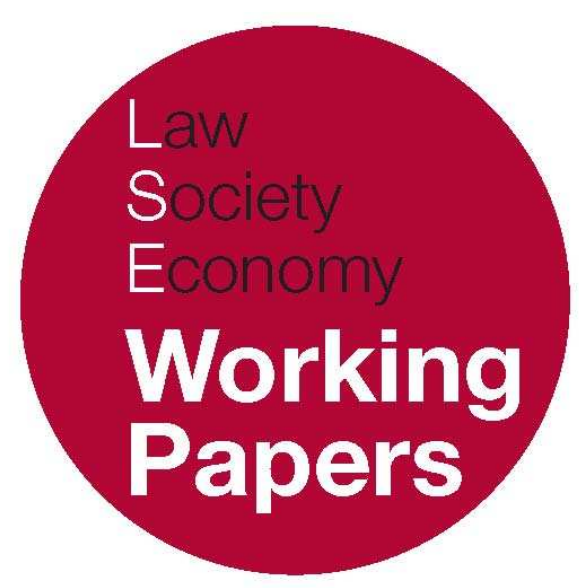

\title{
Psychologising Jekyll, Demonising Hyde: The Strange Case of Criminal Responsibility
}

\author{
Nicola Lacey \\ LSE Law, Society and Economy Working Papers 18/2009 \\ London School of Economics and Political Science \\ Law Department
}

This paper can be downloaded without charge from LSE Law, Society and Economy Working Papers at: www.lse.ac.uk/collections/law/wps/wps.htm and the Social Sciences Research Network electronic library at: http://ssrn.com/abstract=1491625.

(C) Nicola Lacey. Users may download and/or print one copy to facilitate their private study or for non-commercial research. Users may not engage in further distribution of this material or use it for any profit-making activities or any other form of commercial gain. 


\title{
Psychologising Jekyll, Demonising Hyde: The Strange Case of Criminal Responsibility
}

Nicola Lacey ${ }^{*}$

\begin{abstract}
This paper puts the famous story of Jekyll and Hyde to work for a specific analytic purpose. The question of responsibility for crime, complicated by the divided subjectivity implicit in Mr. Hyde's appearance, and illuminated by Robert Louis Stevenson's grasp of contemporary psychiatric, evolutionary, and medical thought as promising new technologies for effecting a distinction between criminality and innocence, is key to the interest of the story. I argue that Jekyll and Hyde serves as a powerful metaphor both for specifically late Victorian perplexities about criminality and criminal responsibility, and for more persistently troubling questions about the legitimacy of and practical basis for criminalisation. A close reading of the story illustrates the complex mix of elements bearing on criminal responsibility-attribution and - incidentally - helps to explain what is wrong with the influential argument that, by the end of the $19^{\text {th }}$ Century, attributions of responsibility in English criminal law already rested primarily and unambiguously on factual findings about the defendant's state of mind. Far from representing the triumph of a practice of responsibility attribution grounded in the assessment of whether the defendant's capacities were fully engaged, I argue that the terrain of mental derangement defences in late $19^{\text {th }}$ Century England helps us to understand that longer-standing patterns of moral evaluation of character remained central to the criminal process even - or perhaps especially - in cases dealing with defects of consciousness. And precisely because 'character' remained key to the institutional effort to distinguish criminality and innocence, the 'terror' of Stevenson's story resides in its questioning of whether either scientific knowledge or
\end{abstract}

* Law Department, LSE. A version of this paper was delivered as the Sanford Kadish Lecture at Boalt Hall Law School, University of California at Berkeley, in April 2009. I am deeply grateful to David Lieberman and Erin Murphy for their astute commentaries on that occasion. An early draft was presented at Warwick University Law School, at the London School of Economics Legal and Political Theory Forum, at Cornell University and at the University of Sydney Law Faculty. I am grateful to the participants on each of these occasions for their feedback, and to Moira Gatens, Arlie Loughnan, Paul Patton, and David Soskice for discussion of the argument and suggestions for reading. The paper was written during my tenure of a Leverhulme Trust Major Research Fellowship: I acknowledge the Trust's support with gratitude. 
moral evaluation of character can provide a stable basis for attributions of responsibility. In conclusion, I will also suggest that Stevenson's tale can help us to make sense of the resurgence of overtly 'character-based' practices of responsibility attribution in contemporary Britain and the United States, which themselves reflect a renewed crisis of confidence in our ability to effect a 'dissociation' between criminality and innocence. The argument proceeds as follows: I first juxtapose a contemporary case at the Old Bailey with the 'case' of Jekyll and Hyde, drawing out and analyzing the narratives of responsibility-attribution to be found in both texts. I then locate this analysis within a broader set of hypotheses about the historical trajectory of ideas and practices of criminal responsibility-attribution. In conclusion, I draw out some implications of this analysis for contemporary criminal law.

\section{INTRODUCTION}

It was on the moral side, and in my own person, that I learned to recognize the thorough and primitive duality of man; I saw that, of the two natures that contended in the field of my consciousness, even if I could rightly be said to be either, it was only because I was radically both; and from an early date, even before the course of my scientific discoveries had begun to suggest the most naked possibility of such a miracle, I had learned to dwell with pleasure, as a beloved daydream, on the thought of the separation of these elements. If each, I told myself, could but be housed in separate identities, life would be relieved of all that was unbearable; the unjust might go his way....; and the just could walk steadfastly and securely on his upward path, doing the good things in which he found his pleasure, and no longer exposed to disgrace and penitence by the hands of this extraneous evil. It was the curse of mankind that these incongruous faggots were thus bound together - that in the agonized womb of consciousness, these polar twins should be continuously struggling. How, then, were they dissociated?1

In early 1886, Strange Case of Dr. Jekyll and Mr. Hyde burst onto the literary scene, selling 40,000 copies in the first six months after publication alone, ${ }^{2}$ entering the 'collective consciousness', ${ }^{3}$ and, in doing both of these things, catapulting the $35-$ year-old Robert Louis Stevenson to fame.

What does this publishing sensation have to do with criminal law? Stevenson was himself trained as a lawyer; he was writing at the end of the second successive century in which English and Scottish fiction had been hugely preoccupied with law, legal processes, and the legal profession; ${ }^{4}$ he devised a plot in which

\footnotetext{
${ }^{1}$ R.L. Stevenson, Strange Case of Dr. Jekyll and Mr. Hyde (hereafter 'Jekyll and Hyde') (1886, Harmondsworth: Penguin, 2002), 56.

2 R. Mighall, Introduction to the 2002 edition of Jekyll and Hyde, ibid, xxxiii.

3 ibid, ix: for evidence of the story's continuing status in popular culture, see 'Shannon's Mother Like Jekyll and Hyde, Court Hears', (14 November 2008) The Guardian, 14.

4 See N. Lacey, Women, Crime and Character: From Moll Flanders to Tess of the d'Urbervilles (Oxford: Oxford University Press, 2008), 43-45; for an example of 19th Century American fiction's distinctive
} 
criminality occupies centre stage; and he presented much of that plot - or, as he entitled it, 'case'5 - in the legally inspired form of testimonial evidence. Moreover, the passage which I have just quoted - an extract from Henry Jekyll's 'full statement of the case' - could be read as a metaphor for anxiety about one of the most persistent myths of criminal justice: the hope, or, in Jekyll's words, 'beloved daydream', that criminality and innocence, right and wrong conduct, good and evil character can readily be distinguished. Throughout the history of criminal justice, this hope reasserts itself, while the technologies available for effecting and legitimating identification of the 'criminal' or 'dangerous' change over time. Indeed, one could argue that the very impulses clearly to define crime and to locate individual or otherwise circumscribed responsibility for it proceed from the same sort of impulse as that which prompts Henry Jekyll to try to project his own anti-social desires onto the separate identity of Edward Hyde, while Stevenson's story speaks to the fragility of any such attempt at separation.

My purpose in this paper is to put Jekyll and Hyde to work for a rather specific analytic purpose. The question of responsibility for crime, complicated by the divided subjectivity implicit in Mr. Hyde's appearance, and illuminated by Stevenson's grasp of contemporary psychiatric, evolutionary, and medical thought as promising new technologies for effecting a distinction between good and evil, criminality and innocence, is key to the interest of the story. In what follows, I shall argue that Jekyll and Hyde serves as a powerful metaphor both for specifically late Victorian perplexities about criminality and criminal responsibility, and for more persistently troubling questions about the legitimacy of and practical basis for criminalisation. A close reading of the story can help to illustrate the complex mix of elements bearing on criminal responsibility-attribution, and - incidentally to explain what is wrong with the influential argument that, by the end of the 19th Century, attributions of responsibility in English criminal law already rested primarily and unambiguously on factual findings about the defendant's state of mind.

Far from representing the triumph of a practice of responsibility attribution grounded in the assessment of whether the defendant's capacities were fully engaged, I shall argue that the terrain of mental derangement defences in late $19^{\text {th }}$ Century England helps us to understand that longer-standing patterns of moral evaluation of character remained central to the criminal process. Precisely because 'character' remained key to the institutional effort to distinguish criminality and innocence - to 'dissociate', in Jekyll's words, the 'incongruous faggots' which are 'bound together' in the 'agonized womb' of not just individual but social 'consciousness' - the 'terror' of Stevenson's story resides in its questioning of

preoccupation with, if not law, at least social control, see N. Hawthorne, The Scarlet Letter (1850, Oxford: Oxford University Press [Oxford World's Classics], 2007) - a story which, like Jekyll and Hyde, speaks to the fear of hidden evil, assuaged in this case by a particularly horrifying social attempt to make bad character manifest.

${ }^{5}$ Jekyll and Hyde is of course a 'case' in both medical and legal senses - as is reflected in the professional identities of the key players. 
whether either scientific knowledge or moral evaluation of character can provide a stable basis for attributions of responsibility. In conclusion, I will also suggest that Stevenson's tale can help us to make sense of the resurgence of overtly 'characterbased' practices of responsibility attribution in contemporary Britain and the United States, which themselves reflect a renewed crisis of confidence in our ability to effect the 'dissociation' to which Jekyll refers.

My argument will proceed as follows: I shall first juxtapose a contemporary case at the Old Bailey with the 'case' of Jekyll and Hyde, drawing out and analyzing the narratives of responsibility-attribution to be found in both texts. I shall then locate this analysis within a broader set of hypotheses about the historical trajectory of ideas and practices of criminal responsibility-attribution. In conclusion, I shall draw out some implications of this analysis for contemporary criminal law.

\section{'THE DEVIL MADE ME DO IT': JULIA SPICKERNELL AND HENRY JEKYLL}

On the $4^{\text {th }}$ of February, 1889 - three years after Robert Louis Stevenson let the respectable Dr Henry Jekyll and his terrifying alter ego, Edward Hyde, loose on the streets of London - 37-year-old Julia Geoegina Spickernell was indicted at the Old Bailey for the 'wilful murder' of her daughter, Mabel Constance. ${ }^{6}$ The facts of the case were devastatingly simple. On the 29th of December, Spickernell called on her downstairs neighbour, Mary Ann Goldring, telling her that 'I have something to show you'. The something, tragically, was the youngest of Spickernell's four children, a nine-month-old girl, whom she had drowned in a pail of warm water. Goldring in turn called out another neighbour, the memorably named Lucy Cavalier, and both women testified to Spickernell's distracted requests for razors or a rope with which she could take her own life. Apart from the testimony of these two neighbours, her trial - predictably enough - was dominated by medical evidence ${ }^{7}$ given by the doctor who had attended her in her confinement, by a police surgeon, and by the medical officer of Holloway Prison. Equally predictably, each of these men tailored their evidence carefully to the doctrinal requirements of the McNaghten Rules which governed then, as they do in England and Wales today, the law on insanity. Two of the witnesses specifically testified that she was 'incapable of appreciating the nature and quality of the act', while a third, echoing late Victorian views on female biology and mental stability, suggested that what was at issue was 'mania' arising from 'over-lactation', adding

6 Proceedings of the Old Bailey t18890204-214 (case citation from the online database of the Proceedings 1674-1913), at http://www.oldbaileyonline.org/.

${ }^{7}$ On the rise of such testimony between the mid-18 $8^{\text {th }}$ and mid-19th Centuries, see J.P. Eigen, Witnessing Insanity: Madness and Mad Doctors in the English Court (New Haven: Yale University Press, 1995). 
his firm opinion that this had rendered her 'temporarily insane'. 8 The jury agreed, and Julia Spickernell was duly found 'guilty of the act, but being insane at the time' and was 'detained until Her Majesty's pleasure be known'.

If these facts marked the limit of the report, there would be little to remark about it: it would be just what we would expect to find in an insanity case of the time, with the only potentially difficult issue arising in relation to the idea of 'temporary insanity', which was still causing some doctrinal controversy. ${ }^{9}$ Doctors dominated the trial: Spickernell's 'pains in the back of her head' reflected the prevailing idea of insanity as physically located in the brain, which governed mind and conduct; and the McNaghten rules structured both testimony and decision. This in turn fits well with what is generally taken to be the prevailing contemporary framework for understanding criminal responsibility: one which is primarily focused on the defendant's state of mind, understood as a factual or psychological matter. ${ }^{10}$

But in fact, terse as the report is, both medical and lay testimony are punctuated by another, very different theme, and one which sits uncomfortably alongside the dominant medicalised and factualised framework in which guilt is premised on a particular state of mind, yet in which, as one philosophical commentator has recently put it, mens is nonetheless analytically distinct from rea. ${ }^{11}$ As Spickernell put it to Lucy Cavalier, 'The devil made me do it; he has been following me about up and down stairs the last five weeks.' And in the words of Philip Francis Gilbert, the medical officer of Holloway Prison,

She sobbed and said she had been an extremely wicked woman, that she had gone through hell, that she had been a wicked wretch all her life, and was unfit to live - besides this, she was under the delusion that she heard a voice that came from the devil, continually accusing her of doing nothing but taking care of herself - she complained of intense headache, that whatever she was doing she heard this voice accusing her of self-indulgence.'

\footnotetext{
8 It is worth noting that this medical testimony seems not to have been unsettled by the Spickernell's immediate confession to her two neighbours and her enormous distress, each of which would seem to indicate her grasp of both what she had done and its wrongfulness. This pattern is repeated in a significant number of cases of the late 19th Century; see for example, those of Benjamin Hewlett, Proceedings of the Old Bailey t18880227-348 ('I am going mad; I have killed my boy') and of Emily Walmsley (ibid, t18830430-550): 'Oh, George, I have killed my poor Rose; fetch the doctor, fetch the police'). This almost certainly reflects the ways in which medical experts were trying to push the limits of the cognitive constraints imposed by the McNaghten rules: see text at $\mathrm{n} 66$ below.

${ }^{9}$ Needless to say, this claim cannot rest on a single case: for a systematic analysis of cases of this type, see J.P. Eigen, Unconscious Crime: Mental Absence and Criminal Responsibility in Victorian London (Baltimore: Johns Hopkins University Press, 2003), 161. Claims of temporary insanity were most often found in cases of drunkenness.

10 As Roger Smith notes in Inbibition: History and Meaning in the Sciences of Mind and Brain (London: Free Association Books, 1992), 25, 'psychology' emerged as a discipline only in the late 19th Century, before which point, "knowledge which we might label "psychological" was part of a broader culture'; see also N. Rose, Governing the Soul: The Shaping of the Private Self (London: Free Association Books, 2nd ed, 1999).

11 T. Nadelhofer, 'Bad Acts, Blameworthy Agents and Intentional Actions: Some Problems for Juror Impartiality’ (2006) 9 Philosophical Explorations 203, 212.
} 
Speaking volumes about the prevailing norms against 'self-indulgence' particularly for women - this passage also conjures up a much older discourse of 'wickedness' and its relation to crime; and, significantly, it inserts this wickedness into a narrative in which the defendant's own responsibility is unsettled by the assertion of a separate agency - in this case that of 'the devil'. ${ }^{12}$ While the doctor deftly subsumes the devil within a medical discourse of delusion, his references to 'wickedness' float outside the medical frame and testify to the enduring association of crime with bad character and/or with the power of evil, understood in terms of a variety of theological (mainly Christian) doctrines. The case therefore gives rise to questions about the triumph of a psychologised, factual approach to responsibility. And it raises a spectre which haunted late Victorian criminology and popular culture: the spectre of states of absence or duality of mind as undermining the stable, unitary subject central to Victorian projects of selfmanagement and social control. ${ }^{13}$

Just as Julia Spickernell's case could be read as a classic instance of medicalised insanity and psychologised criminal responsibility, so Robert Louis Stevenson's Strange Case of Dr. Jekyll and Mr. Hyde 14 is generally thought of as a product of Stevenson's undoubted interest in, and knowledge of, contemporary medical science and evolutionary theory. ${ }^{15}$ Presented as a 'case' from the points of view of two doctors and a lawyer, the essential lines of the story are well-known. A socially distinguished and intellectually talented doctor, Henry Jekyll - a man 'in the very pink of the proprieties'16 - is driven by curiosity in chemical research and by a desire to disguise his taste for 'low' pleasures through the adoption of an alternative identity. With these motivations, he devises a potion which allows him to escape his generally 'self-denying toils' 17 by turning himself temporarily into the reckless Edward Hyde. But Hyde's pleasures do not stop with the sexual excesses at which Stevenson hints, but gradually expand to embrace violence and, ultimately, wanton murder. As time goes on, Hyde's personality and body become dominant, and the transformative drug begins to lose its efficacy: when

\footnotetext{
12 In doing so, it also introduced a narrative which was uncomfortably close to the difficult terrain of 'irresistible impulse', on which, see text following n 54 below: no wonder that two of the three medical witnesses were so careful to quote the cognitive test from the McNaghten Rules in their testimony.

${ }^{13}$ See J.P. Eigen, Unconscious Crime: Mental Absence and Criminal Responsibility in Victorian London, $\mathrm{n} 7$ above; I. Hacking, Rewriting the Soul: Multiple Personality and the Sciences of Memory (Princeton: Princeton University Press, 1995).

14 n 1 above.

15 Robert Mighall points out close analogies, for example, between Stevenson's formulations and the contemporary work of Henry Maudsley and of Theodule Ribot's conception of 'higher and lower selves': in the 2002 edition of Jekyll and Hyde (n 2 above), see R. Mighall's introduction (xxiv) and his essay, 'Diagnosing Jekyll: The Scientific Context to Dr Jekyll's Experiment and Mr Hyde's Embodiment', (146, 151); he also points out that Stevenson's wife recorded that the tale was inspired by his reading of a French scientific article about sub-consciousness (145). Nancy K. Gish has persuasively suggested that the scientific source of Stevenson's 'case' was Pierre Janet's theory of hysteria as grounded in split personality caused by dissociated consciousness: 'Jekyll and Hyde: The Psychology of Dissociation' (2007) 2 International Journal of Scottish Literature 1.

16 Stevenson, n 1 above, 9.

17 ibid, 64.
} 
Jekyll is finally effaced, leaving only the trace of his documentary 'statement of the case', Hyde is forced to commit suicide in order to escape the gallows.

Hyde's small physical stature and repellent features, along with what we would call today a psychopathic lack of affect or guilt, evoke an atavistic figure, an 'ape-like', ${ }^{18}$ 'troglodytic'19 survival within the highly evolved Jekyll - and within 'civilised' Victorian society - of a primitive state of being. Moreover, Jekyll's need to create Hyde in the first place represents Stevenson's evocation of the psychological costs of civilization. Jekyll seeks to displace his own responsibility by creating Hyde: 'It was Hyde, after all, and Hyde alone, that was guilty'; 'Think of it - I did not even exist! Let me but escape into my laboratory door, give me but a second or two to mix and swallow the draught...; and whatever he had done, Edward Hyde would pass away like the stain of breath upon a mirror';20 But since Jekyll (at least initially) exercises 'the power of voluntary change'21 to become Hyde, he (perhaps) bears responsibility for the upshot of that decision. Indeed, the disturbing implication is that, notwithstanding the split identity, Jekyll in some senses is Hyde: as Jekyll himself puts it, 'This, too, was myself.'22 Granted, this brings with it a more comforting notion that, ultimately, individual responsibility cannot be evaded. At the social level, however, the implications of the story are unavoidably disturbing, for Hyde resides within Jekyll; as Jekyll puts it, he is 'the evil side of my nature'; the 'lower elements in my soul'. 23 Hyde is inserted seamlessly into a respectable bourgeois environment and, notwithstanding his repellent features, has the unmistakable deportment and tastes of a gentleman. ${ }^{24}$ Hence, the story challenges the very project of distinguishing and regulating criminality. ${ }^{25}$ Moreover, Stevenson arguably implies that 'civilized' society - like Dr. Jekyll - in effect 'creates' and hence bears responsibility for its criminal underside.

Themes from contemporary criminology, evolutionary theory, and medical psychology are prominent in Stevenson's story, and its resultant resonance with prevailing social preoccupations doubtless accounts to some extent for its instant and lasting success. But - like the case of Julia Spickernell - the 'case' of Jekyll and Hyde is not marked only by this modern, medical-psychological, and biological theme. ${ }^{26}$ Originally written for the 'Christmas Crawler' market of spine-chilling

\footnotetext{
$18 \mathrm{ibid}, 22$; among the burgeoning theories about the sources of Stevenson's imaginative creation, of interest in the context of this reference to Hyde as Jekyll's 'animal' side is Chris Danta's account of Stevenson's reaction to Darwin and his moral objections to vivisection, which Danta argues derived from a sense of the inextricable links between animal life and human existence: 'The Metaphysical Cut: Darwin and Stevenson on Vivisection' (forthcoming, 2010) 36 (2) Victorian Review: an Interdisciplinary Journal of Victorian Studies.

${ }^{19}$ Stevenson, $\mathrm{n} 1$ above, 16

20 ibid, 60, 61; cf 67: 'He, I say - I cannot say, I.'

21 ibid, 62.

22 ibid, 58.

23 ibid.

${ }^{24}$ I am grateful to David Lieberman for alerting me to the significance of this point.

${ }^{25}$ Stevenson, n 1 above, 57.

26 Another modern theme - that of professional detective work - is represented by the aptly named 'Inspector Newcomen': ibid, 24.
} 
stories, Strange Case of Jekyll and Hyde is an unmistakable - if a particularly distinguished - member of the Gothic tradition in English literature. This is significant in terms of the images of criminality which we would expect to find in the book. From the mid-1 $8^{\text {th }}$ Century on, as the novel gradually claimed a place in polite society and high culture, the description and analysis of criminality which had formed a place in the work of early writers like Defoe and Richardson were rapidly evacuated from the 'Realist' tradition and displaced onto the 'Gothic' novels of Walpole, Lewis, Radcliffe, and others. ${ }^{27}$ To paint with very broad brush strokes, this strand of literature diversified in the $19^{\text {th }}$ Century into a variety of forms such as the 'Newgate Novel', the 'novel of sensation', and horror stories, ghost stories, and science fiction. ${ }^{28}$ Like Mary Shelley's Frankenstein at the start of the 19 ${ }^{\text {th }}$ Century, ${ }^{29}$ Stevenson's Jekyll and Hyde at its end is therefore concerned not only with the modern theme of interior subjectivity and psychological responsibility, or with medically or socially determinist accounts of criminality such as those which dominate Dickens' later work, ${ }^{30}$ but also with an older theme of 'hellish' evil, of 'the slime of the pit' appearing on earth. ${ }^{31}$ Much the same combination of religious and scientific cosmologies characterises other instances of a significant genre of what we might call 'double consciousness' narratives throughout the $19^{\text {th }}$ Century, notably James Hogg's curious Confessions of a Justified Sinner (1824) and Oscar Wilde's The Picture of Dorian Gray (1890). ${ }^{32}$ In each case,

27 H. Walpole, The Castle of Otranto (1764) and M. Lewis, The Monk (1796) in Four Gotbic Novels (Oxford: Oxford University Press, 1994), 5, 159: Ann Radcliffe, The Mysteries of Udolpho (1792, UK: Penguin Classics, 1998): for discussion of criminality in the Gothic tradition, see Lacev, n 4 above, 80-81, 122-124: J. Schramm, Testimony and Advocacy in Victorian Law, Literature and Theology (Cambridge: Cambridge University Press, 2000), ch 3. Stevenson's story also exhibits, in the atavistic Hyde, a pervasive Gothic preoccupation with the degeneration of elite lineage.

28 This is not to say, of course, that this was an autonomous strand of writing. Unambiguously 'Realist' novels like those of George Eliot display some 'Gothic' themes, while novels of sensation like those of Wilkie Collins also show elements of 'Realism'; Thackeray's Vanity Fair (1848, UK: Penguin Classics, 2001) is a hybrid between realist and Newgate novel; Charlotte's and Anne Brontë's Social Realism is shot through with Gothic themes and images; and Dickens occupies a fascinating borderland between Realism, novels of sensation, and the Gothic.

${ }^{29}$ M. Shelley, Frankenstein, or, The Modern Prometheus (1818) in Four Gotbic Novels, n 27 above. The analogies between Jekyll and Hyde (Stevenson, n 1 above) (written, coincidentally, in Bournemouth, where Mary Shelley is buried) and Frankenstein are striking. Even leaving aside the common theme of a scientist's inadvertent creation of a monstrous being whose 'foul soul' transfigures 'its clay continent' (Stevenson, $\mathrm{n}$ 1 above, 16), take for example the shared image of that being's looking through the bed curtains at his creator: Stevenson, n 1 above, 13; Shelley, n 29 above, 491.

${ }^{30}$ See P. Collins, Dickens and Crime (London: Macmillan, $2^{\text {nd }}$ ed, 1965); see also M. Wiener, Reconstructing the Criminal: Culture, Law and Policy in England, 1830-1914 (Cambridge: Cambridge University Press, 1991).

31 Stevenson, $\mathrm{n} 1$ above, 69.

32 J. Hogg, The Private Memoirs and Confessions of a Justified Sinner (1824, Oxford: Oxford University Press [Oxford World's Classics] 1999); O. Wilde, The Picture of Dorian Gray (1890, Oxford: Oxford University Press [Oxford World's Classics], 2006). In Hogg's early example of this fascinating genre, a young Calvinist is haunted and corrupted by an alter ego or second self (116-117) who is clearly suggested to be 'an agent of the devil' (121), and whose voice is described as 'the sound of the pit' (188). Yet even this early $19^{\text {th }}$ Century text throws in copious hints of madness or a diseased imagination in a single self (154). In Wilde's very different text, whose dark hints of an ostensibly respectable man's degenerate life in the London underworld echo Jekyll and Hyde, the original corrupting/creative force is itself split between a decadent, Mephistotelian aristocrat, Lord Henry Wotton, and Dorian Gray himself. But once again the text introduces a curious mixture of the twin themes of madness and a of a supernatural splitting off of the apparently decent public self from the evil and sinful self made manifest only in Gray's portrait (78- 
the authors speak to the persistent social problem of how to distinguish between good and evil, right and wrong, and of how to create institutions capable of delivering and legitimating such judgments.

In Stevenson's tale, this preoccupation with lurking evil and how to ascribe responsibility for it is underlined by a welter of biblical references, doubtless reflecting the Presbyterian background from which he had rebelled, but which followed him through his literary journey. ${ }^{33}$ Both Jekyll's and Frankenstein's experiments evoke the story of original sin, with its vision of the human search for knowledge as a flouting of traditional authority and a flirting with evil and/or the devil. ${ }^{34}$ While the story invites us to evaluate Hyde's conduct and character as unambiguously evil, it complicates our judgment by implying that he and Jekyll are, in effect, the same person. Hugely innovative, Stevenson's Jekyll and Hyde took the longstanding preoccupation of Gothic literature with terror and the supernatural and removed them from history and distance, placing them firmly in the here and now of late 19th Century London and the world of science. This resulted in a tale which is not only a powerful allegory of late Victorian society, but also a suggestive metaphor for many persisting themes in criminal justice.

\section{PSYCHOGISING JEKYLL'S RESPONSIBILITY; DEMONISING HYDE'S CHARACTER?}

In using Stevenson's tale as a metaphor to frame my interpretation of the structure of criminal responsibility-attribution both in and beyond the late 19th Century, I am drawing on - but also refining - a hypothesis which I have developed and defended at greater length in a recent book and in a number of articles over the last decade. ${ }^{35}$ The key assumption of this work is that patterns of responsibility-

$79,81-82,109)$. Here, scientific and religious/supernatural cosmologies are yet more closely interwoven than in the earlier texts. Another interesting example of the double consciousness genre is George Eliot's short story The Lifted Veil, Brother Jacob (1859, Oxford: Oxford University Press [Oxford World's Classics], 1999). Here, however, the doubled consciousness of a young clairvoyant concerns not so much a split in his own subjectivity, but access to other minds and to future events. Characterised by an unusual inflection of the Gothic amid Eliot's decisively Realist work, the book was prompted in part by her interest in contemporary phrenology, in mesmerism, and in physiology - notably Henry Holland's theory that the double hemisphere of the human brain could on occasion, in cases of injury or disease, lead to double consciousness (see Helen Small's introduction to the Oxford World's Classics edition, xvii-xxii). In Eliot's text, there is no hint of the influence of sin or evil on the clairvoyant; the preoccupation is rather with the psychological implications and moral upshot of contemporary science.

${ }^{33}$ See Robert Mighall's introduction to Jekyll and Hyde, n 1 above, xxi-ii.

${ }^{34}$ Both stories raise a fascinating set of moral questions about the responsibility of the creator - moral questions which are prompted or at least complicated by scientific advance: in these narratives, science is not so much the solution as it is the problem.

35 See in particular Lacey, n 4 above, 'In Search of the Responsible Subject: History, Philosophy and Criminal Law Theory' (2001) 64 MLR 350, 'Responsibility and Modernity in Criminal Law' (2001) 9 Journal of Political Philosophy 249, 'Space, Time and Function: Intersecting Principles of Responsibility Across the Terrain of Criminal Justice' (2007) 1 Criminal Law and Philosophy 233, and 'Character, Capacity, Outcome: Towards a Framework for Assessing the Shifting Pattern of Criminal Responsibility in Modern English Law' in M. Dubber and L. Farmer (eds), Modern Histories of Crime and Punishment (Palo Alto: 
attribution relate to the roles and needs of a criminal justice system - to a political need for legitimation and to a practical need to specify and co-ordinate the sorts of knowledge which can be brought into a courtroom. The imperatives set by these needs for legitimation and co-ordination are changing over time, as the political, cultural, institutional, and economic environment of the criminal process shifts. By the late $1^{\text {th }}$ Century, these needs had been affected by a welter of social changes, notably the spread of democratic sentiments and entitlements. Furthermore - equally importantly - the institutional resources available to meet these needs were radically different from what they had been a century before.

Let me briefly set out my account of how practices of criminal-responsibilityattribution changed over the $18^{\text {th }}$ and $19^{\text {th }}$ Centuries, as understood within this overall framework. In the $18^{\text {th }}$ Century, the operative assumption underlying an attribution of criminal responsibility was that the defendant's conduct exhibited or expressed bad character: this was a holistic judgment of wrongful conduct and dangerousness rather than today's supposed analytical separation of (external) conduct from (internal) 'mens rea'. The trial afforded the defendant the opportunity of exculpating him- or her-self - and indeed it was out of these developing arguments about defences that the elaborated doctrine of responsibility as something which had to be proven for inculpation eventually emerged in the latter half of the $19^{\text {th }}$ Century. Meanwhile, the key variable in most criminal trials was the defendant's capacity to gather together credible people willing to speak for her and back up her testimony. Even when the defendant's mental state was unavoidably at issue, attributions of responsibility were based on judgments about the quality of character displayed in conduct, rather than on a careful investigation of the whether the defendant's cognitive and volitional capacities were fully engaged in the relevant action.

The $18^{\text {th }}$ Century criminal process appears accordingly to have operated quite effectively without the doctrines of responsibility-attribution which now form the backbone of criminal law. Today, the state's responsibility to prove not only conduct, but also individual responsibility lies at the heart of criminal law's legitimation as a system of justice rather than one of sheer force: the fairness of criminalisation is fundamentally premised on the idea that an offender's capacities of understanding and self-control were properly engaged at the time of the alleged offence. In the $18^{\text {th }}$ Century, by contrast, culpability requirements such as having acted 'maliciously', 'wickedly', or 'feloniously' were far from equating to the psychological and capacity-based requirements of 'mens rea' - literally, a guilty mind - with which we are now familiar. Many modern commentators have assumed that 'mens rea' was already a feature of English criminal law by the $18^{\text {th }}$ Century. But there are practical and conceptual reasons to doubt this assumption. First, in the light of institutional features such as speed of trial, lack of legal argumentation, and predominance of lay justice, it seems unlikely that the run-of-the-mill $18^{\text {th }}$ Century trial process could have managed evidence of 'mens rea' in the modern,

Stanford University Press, 2007). 
psychological sense as a formal object of proof. Second, and more fundamentally, as Jeremy Horder has argued, ${ }^{36}$ concepts such as 'malice' in early modern criminal law operated in significantly different ways from modern notions of 'mens rea', and invited not the finding of a 'state of mind' or even attitude, but rather a holistic evaluation of conduct.

So how did responsibility-attribution work? Beyond an assumption of capacity (which could be displaced by evidence of manifest insanity), the trial was focused not on internal questions about the defendant's state of mind, but rather on external facts of conduct. Where evidence about conduct was questionable, the patterns of attribution based on knowledge about character and reputation, which dominated the pre-trial process, also informed the trial itself. In effect, then, a judgment of criminal responsibility was a judgment of bad character.

This pattern of character-based responsibility-attribution, which I maintain dominated the $18^{\text {th }}$ Century criminal trial, and persisted in some areas long into the 19th Century, shares some obvious features with George Fletcher's deservedly influential notion of 'manifest criminality'. I seek to account for the emergence and influence of this distinctive pattern of responsibility-attribution in terms of a more encompassing historical and institutional explanation than Fletcher is willing to give. The pattern of 'manifest criminality' rests on the assumption that crime is readily recognisable by members of the community. It is therefore underpinned by a belief in a widely shared ability to make confident evaluations on the basis of appearances (a confidence, the loss of which is, of course, a key theme in Stevenson's tale). In Fletcher's account, this pattern of manifest criminality is gradually displaced in the $19^{\text {th }}$ Century by a 'subjective pattern' which locates criminality in the intention of the defendant, alongside a 'harm- or risk-based pattern' which focuses on outcomes or potential outcomes. ${ }^{37}$ Why should this have been the case? My argument is that the institutional mechanisms needed to render subjective responsibility an object of proof in a criminal trial were not yet in place in the $18^{\text {th }}$ Century, nor was the lack of them yet felt to be a pressing practical or ethical problem in a world which had yet to make Maine's famous move from 'status to contract', and in which the institutional mechanisms supporting findings of 'manifest criminality' remained, conversely, relatively robust. But this world was beginning to change, and the 'long $18^{\text {th }}$ Century' saw the gradual assembly of many of the doctrines and institutional arrangements which we take for granted as features of criminal law today.

In the context of my hypothesized trajectory from primarily 'character-based' attributions of responsibility to those trained rather on the defendant's mental state or engaged capacities, the late $19^{\text {th }}$ Century presents itself as an interesting focus. By this time, most of the institutional changes which distinguish the modern criminal justice system - legal representation by defence lawyers, systematic law reporting, an organised legal profession, a developed law of

${ }^{36}$ J. Horder, 'Two Histories and Four Hidden Principles of Mens Rea' (1997) 113 LQR 95.

${ }^{77}$ G. Fletcher, Retbinking Criminal Law (Toronto: Little, Brown, 1978). 
evidence, a professional police - were in place. And the growth of what we would now call the medical and psychological sciences had rendered plausible and, presumptively, practicable a trial process which set up the state of a defendant's mind as an object of proof. Moreover, these legal and procedural changes arguably mapped on to a deeper set of changes in ideas of human identity or selfhood. While social institutions in the still stratified and relatively stable world of $18^{\text {th }}$ Century England exhibited a confidence about reading character, credit, and even conduct from status ${ }^{38}$ and surface, the more mobile, urbanised world of the $19^{\text {th }}$ Century was generating a new set of co-ordination problems by undermining the practical basis for these individual assessments. At the same time, it was experiencing an acute legitimation need, as emerging democratisation posed a demand for more individualised assessments of credibility, while the emergence of the romantic movement had consolidated a developing trend to see the essence of human identity as residing not in the external markers of conduct, but rather in the inner recesses of the mind or soul. ${ }^{39}$

Furthermore, this was a rapidly changing world and one in which conflict about even core values informing an (itself expanded) criminal law was on the increase. In this context, and that of the rapidly expanding regulatory tasks to which criminal law was being put, as Lindsay Farmer has argued, ${ }^{40}$ the traditional notion of crime as reflecting a widely shared notion of 'public wrong' became elusive. The result was that, as confidence in consensus and in the recognisability of criminal conduct declined, even among elites, the weight of criminal law's legitimation was projected onto the proof of individual responsibility, conducing to a decline of evaluative notions of responsibility such as acting 'maliciously' or exhibiting 'bad character', and to a rise of 'factualised' notions of responsibility such as 'intention'. ${ }^{41}$ In each of these contexts, the promise of scientific insight into the workings of the human mind was seductive indeed.

But had 'character' disappeared? Or had it merely been realigned in relation to the newer discourses of responsibility-attribution? Even in London, evidence about character and reputation remained important to social control: the Old Bailey insanity cases in the 1880s feature copious character evidence, while Conley's study of late Victorian Kent shows that 'local knowledge' and informal mechanisms of judgment remained central to criminal justice control. ${ }^{42}$ Indeed, the persisting importance of character and reputation to social control surfaces in Stevenson's tale: the witnesses to one of Hyde's misdemeanours effectively coerce

\footnotetext{
38 Much the same was true in the areas of finance and science: see respectively, M.C. Finn, The Character of Credit: Personal Debt in English Culture, 1740-1914 (Cambridge: Cambridge University Press, 2003); S. Shapin, A Social History of Truth: Civility and Science in Seventeenth-Century England (Chicago: University of Chicago Press, 1983)

${ }^{39}$ D. Warhman, The Making of the Modern Self (New Haven: Yale University Press, 2004).

${ }^{40}$ L. Farmer, Criminal Law, Tradition and Legal Order (Cambridge: Cambridge University Press, 1997) chs 1 and 4.

41 Alan Norrie, Crime, Reason and History (London: Butterworths, 2nd ed, 2001); Lacey, 'In Search of the Responsible Subject', n 35 above.

42 C.A. Conley, The Unwritten Law: Criminal Justice in Victorian Kent (Oxford: Oxford University Press, 1991).
} 
him by threatening that, if he fails to make compensation, 'If he had any friends of any credit ... he should lose them'. ${ }^{43}$ But could the 'economy of character' ${ }^{\prime 4}$ any longer be relied upon as a social mechanism for distinguishing criminality? And were either the surface signals of human character or the psychological depths of engaged human capacity legible by the late Victorian criminal courts?

\section{THE PSYCHOLOGISATION OF IRRESPONSIBILITY?}

On the hypothesis which I have presented, many of the decisive processes of institutional modernisation and law reform were either complete, or well underway, by the last quarter of the $19^{\text {th }}$ Century. It might be therefore be assumed that the pattern of capacity-based, internal, or subjective criminality - at least outside the terrain of strict liability offences - would have been firmly established by the time that Jekyll and Hyde was written. The gradual rise of the 'sciences of mind and brain' and of medical testimony in cases of possible mental incapacity would give a further basis for confidence in that assumption. But would the assumption be justified?

In this section, I ask whether the move towards a psychological model of criminal responsibility was really complete by the era of Jekyll and Hyde.45 In examining this question, the treatment of what we today would call mental incapacity defences, in which what would become the psychiatric profession was emerging as an authoritative witness to the 'facts of the mental matter', is a particularly instructive case study. In principle, the field of mental incapacity should reflect the most fully developed aspect of the 'inner' or 'psychological' model of criminal responsibility. To the extent that it does not do so, this raises interesting questions about the decline of an evaluative/character-based practice during the era of modernisation.

Let us turn the clock back once again to remind ourselves of how matters of specifically mental incapacity were dealt with before $18^{\text {th }}$ Century English criminal courts. Their handling is striking to the modern legal gaze. Though rules excluding the testimony of witnesses on grounds of incompetence were already developing in the $18^{\text {th }}$ Century, ${ }^{46}$ there was no statutory recognition of an insanity defence until 1800 and no elaborated common law definition of insanity until the

\footnotetext{
43 Stevenson, n 1 above, 16.

44 See D.S. Lynch, The Economy of Character: Novels, Market Culture and the Business of Inner Meaning (Chicago: University of Chicago Press, 1998).

$45 \mathrm{My}$ inclination is to argue that they were not in fact fully established until the middle of the $20^{\text {th }}$ Century and that even then, they occupied only part of the terrain of criminal law. This is an argument which I will not elaborate here, but which turns on the continuing doctrinal significance of the presumption that a person intends the natural consequences of his or her actions: see Lacey, 'In Search of the Responsible Subject', n 35 above, 367, 370 .

46 See E.P. Judge, Character Witnesses: Credibility and Testimony in the Eighteenth Century Novel (D.Phil. thesis, Dalhousie University, 2004), ch 4.
} 
McNaghten rules were formulated in $1843 .{ }^{47}$ Of course - as remains the case today - many potential insanity cases would have been filtered out of the criminal process long before they came to trial. But, as records show, significant numbers of putatively insane defendants nevertheless reached the courts: Joel Peter Eigen identified 331 cases before the Old Bailey between 1760 and 1843 in which issues of mental derangement were raised as possible defences. ${ }^{48}$

When such cases did reach the courts, their disposal was shaped by commonsense jury assumptions about madness and its implications for the vicious will which underpinned culpability. That there is little sign of any analysis of the definitions of insanity discussed by treatise writers like Hale or Blackstone in most of the run-of-the-mill cases reported in the Proceedings of the Old Bailey should come as no surprise given the usual absence of defence lawyers. And while medical testimony was gradually emerging as a relevant matter, it was in its early forms itself closely articulated with various forms of lay knowledge and understanding, as indeed was to be expected given that the formal organisation of the medical profession was far from having gained a monopoly over broadly medical practice. ${ }^{49}$ As Arlie Loughnan has argued,50 the prevailing pattern here again echoing George Fletcher's notion of 'manifest criminality'51 - was a pattern of 'manifest madness': insanity was simply what a jury recognized as such, and the system worked on the basis of a deep implicit confidence in the institutional capacity of the trial to 'read' criminal responsibility from character and conduct.

In this rather fluid legal context, as Dana Rabin has shown, prevailing cultural influences had a decisive and direct effect upon legal practices. ${ }^{52}$ Rabin marshals evidence that the emerging culture of sensibility in the latter part of the $18^{\text {th }}$ Century prompted defendants to push the boundaries of what had conventionally been understood as insanity to embrace a wide variety of states of emotional distress, gradually introducing into the courtroom a mind-body distinction which was quite new and which reflected both the emerging idea of human identity as residing in a mental interior and an institutional confidence in the capacity of the trial process to investigate that interior. This process was ultimately seen as threatening to the integrity of the law's prohibitions and was accordingly closed off through the increasingly technical specification of the conditions for the

${ }^{47}$ M'Naghten's Case (1843) 10 Clarke and Finnelly 200.

${ }^{48}$ Eigen, (n 7 above), 6; the annual rate grew slowly from 33 in the 1760s to 71 in the 1830s, by which time, the insanity defence had already undergone some formalisation. The overall rate, however, was low, amounting to between 4 and 8 cases per 1000 . On the gradual rise of insanity pleas, and on the history of the insanity defence in general, see also N. Walker, The Historical Perspective (Crime and Insanity in England Volume 1) (Edinburgh: Edinburgh University Press, 1968) chs 3-4.

${ }^{49}$ Eigen, $n 7$ above, chs 4-6.

50 A. Loughnan, 'Manifest Madness: Towards a New Understanding of the Insanity Defence' (2007) 70 MLR 379; see also R. Smith, Trial by Medicine: Insanity and Responsibility in Victorian Trials (Edinburgh: Edinburgh University Press, 1981), ch 7, which illustrates that even in the 19th Century, non-technical assumptions about female insanity continued to inform the trial process, with infanticide cases in particular often tried without medical evidence being led; see also Lacey, n 4 above, 20-23.

${ }^{51}$ Fletcher, $\mathrm{n} 37$ above.

52 D. Rabin, Identity, Crime and Legal Responsibility in Eighteenth Century England (London: Palgrave Macmillan, 2004), ch 3. 
insanity defence being developed in case law from the early 19th Century onwards. ${ }^{53}$

How does this story continue, as we trace its path through the $19^{\text {th }}$ Century? In Rabin's account, we see the interest in subjective experience - in what we would today call psychology - pressing its way onto the trial's agenda. This was only to be expected: John Locke's 'sensational psychology', after all, dated back to the late $17^{\text {th }}$ Century and found expression in cultural forms such as the novel from at least the 1720s onwards, while the image of selfhood as residing in an authentic inner depth, marked by not only experience, but also a level of continuity and integration, was gaining currency from the latter part of the $18^{\text {th }}$ Century. ${ }^{54}$ But ironically, as Rabin shows, the increasing cultural acceptance of the power of psychological experience and of its relevance to individual responsibility, which legitimated a more expansive terrain of defences, simultaneously posed co-ordination problems for criminal law - problems about both the trial's capacity adequately to assess lay and expert evidence of such states and consequently about the capacity of the recognition of 'psychological' excuses to undermine the law's prohibitions. The law's response was to try to focus mental incapacity defences exclusively onto cognitive as opposed to volitional incapacities: the undoubted power of emotional forces was sidelined in an insanity test focused on radical cognitive defects, finally concretised in the McNaghten Rules' test of a failure to 'know the nature and quality of [the] act'. This, surely, epitomised the psychological world-view, and in widening the already opened doorway to the 'alienist' witness, it further undermined the process of lay evaluation which had underpinned the practice of mental incapacity exculpation for the past centuries.

Or did it? In fact, the matter was very much more complicated. We can begin to see why when we remind ourselves of the fact that the cognitive failure which had to be proven under the McNaghten rules could take one or two forms: it could be either an inability to know the nature and quality of the act or, if the defendant did know it, an incapacity to 'know right from wrong'. The idea of 'knowing right from wrong' is, of course, an inextricable mix of fact and evaluation. So it is hardly surprising that the latter $19^{\text {th }}$ Century was marked by a persistent debate about the concept of 'moral insanity' - the key point at which pressure for the expansion of the defence, to cover, in effect, cases of volitional defect, failures of self-control was applied. Undaunted, and afforced by the emerging doctrines of 'mens rea', medical witnesses made repeated attempts to

\footnotetext{
${ }^{53}$ As Rabin also notes, the $18^{\text {th }}$ Century cases often display what is to our eyes a strange blurring of the concepts of criminal intention and character: indeed, the idea that intent simply was a matter of character underpinned the $17^{\text {th }}$ Century willingness to contemplate poverty as an excuse for crime (ibid, 87-89); not until a case of 1787 , does her sample of mental incapacity cases feature a decisive judicial attempt to separate, analytically, the question of character from that of mental state 9 (ibid, 160): the case is that of Francis Parr, Proceedings of the Old Bailey t17870115-1. For an early example, see the judgment of Chief Justice Holt in Margridge (1707) Kel 119; my point, however, is that such examples were isolated. I am grateful to Jeremy Horder for alerting me to this case.

${ }_{54}$ Warhman, n 39 above; Lacey, n 4 above, ch 1.
} 
establish a defence of 'irresistible impulse' and, where unable to frame a defence of insanity cast as a 'lesion of the will', took their campaign into the terrain of 'mens rea' as a whole, arguing that a damaged will undermined criminal responsibility. ${ }^{55}$ If, to quote one medical witness, 'a person in a state of acute mania would not think about the moral quality of her acts', ${ }^{56}$ and if the inability to 'know right from wrong' itself flowed from a deranged judgment, the gap between someone who 'just couldn't help themselves' and someone who 'failed to understand what they were doing' is perilously fine - as Julia Spickernell's case illustrates.

It is therefore important not to exaggerate the apparent shift from an evaluative to a scientific world-view. For the late Victorian discourses of criminal pathology themselves were, like the discourse of 'mind doctors' of the era, imbued with evaluations of moral character. ${ }^{57}$ This is vividly exemplified in the famous debate about so-called 'moral insanity', a pseudo-medical concept which, as Lucia Zedner puts it, 'equated mental health with virtue....58, and which was applied with particular intensity to women. It is true that by the very end of the Century, there was a tendency to regard habitual offenders in terms of pathology: women "less as "bad" than as "mad" 59 and men as falling into a number of quasibiological groupings which found statutory expression (for both sexes) in the late $19^{\text {th }}$ and early $20^{\text {th }}$ Century. ${ }^{60}$ But for most of the $19^{\text {th }}$ Century, the tendency was to rely on open-textured concepts such as 'moral insensibility' and hence to locate criminality in the failings of properly moral character rather than in psychological incapacity. ${ }^{61}$

Throughout the second half of the 19th Century, the concept of 'moral insanity' was drawn on to conflate capacity, conduct, and character, focussing on external signals of danger or degeneracy rather than internal features of psychology and intentionality. And this continuing focus on character is reflected in a number of other tangible institutional arrangements. For example, the impressionistic category of 'the criminal classes' - those of bad reputation and/or

55 J.P. Eigen, 'Lesion of the Will: Medical Resolve and Criminal Responsibility in Victorian Insanity Trials' (1999) 33 Law and Society Review 425 (see in particular 442).

56 Case of Emily Walmsley, Proceedings of the Old Bailey t18830430-550, testimony of Charles Wheeler, surgeon.

57 As Ruth Harris has shown in Murders and Madness: Medicine, Law and Society in the Fin de Siècle, Oxford: Oxford University Press, 1989), much the same mélange of medicine and moralism characterised debates about criminal responsibility in late $19^{\text {th }}$ Century France.

${ }^{58}$ L. Zedner, Women, Crime and Custody in Victorian England (Oxford: Oxford University Press, 1991), 270.

59 ibid, 46.

${ }^{60}$ See L. Radzinowicz and R. Hood, The Emergence of Penal Policy in Victorian and Edwardian England (Oxford: Oxford University Press, 1990) chs 8-12.

${ }^{61}$ In passing, it is worth noting that the persistence of concepts such as 'moral insanity' puts a different spin on the 'turf wars' between doctors and lawyers charted by Roger Smith in his influential account of criminal insanity in 19 th $^{\text {th }}$ Century England (n 50 above). Smith argues that medicine and law were in competition because while law sought to make an evaluative judgment based on an assumption of responsibility, medicine sought to make a factual judgment on the basis of determinist assumptions. The moral insanity debate suggests that what was at issue was rather a pair of competing evaluations. On the role of 'moral insanity', and the resonance with James Cowles Prichard's influential 1835 text on insanity in Jekyll and Hyde, see Mighall, n 2 above, 147-148. 
with previous convictions - was regarded as hugely important to the identifiability of those thought to be 'vicious in character'.

These findings from the criminal process are strongly reinforced by Roger Smith's study of the historical journey of the concept of 'inhibition' - a usefully ambiguous idea which was central to the Victorian project of regulation precisely because of the way in which it spanned scientific and evaluative resonance. The relationship went in two directions: while 'the social value of the self-regulated person - someone with a "good character" - was a coherence condition for any scientific theory of mental or bodily control', 'the evaluation of human conduct was constitutive in comprehending the bodily or mental conditions making organized activity possible.' Hence, as Smith puts it, '[p]hysiology was not in conflict with ethics. If physiological science provoked a "crisis" about what it was to be human, this was as much a crisis of coherence within science as between science and wider culture.' ${ }^{2}$ The highly contested nature of scientific theories of mind and brain rendered them exceptionally fragile legitimating sources for criminal law. So the body - or more accurately, bodies - of knowledge which the emerging sciences were producing did not stand against common sense and lay evaluation. Rather, they found their force when grounded within a shared discourse and found much of their ground of legitimation and practical mobilisation within those co-existing social resources. ${ }^{63}$

Smith's argument gives further depth to our understanding of why volitional defects were so threatening to the law. 'Inhibition', understood as the capacity for self-control, and as a concept with both scientific and evaluative dimensions, was the condition for the very project of Victorian governance. But the ambiguity of 'inhibition' further suggests the precise nature of a re-articulation of older ideas of character with the newer psychologised discourse of self-control: good character simply became the capacity for self-mastery which dominated the moral discourse of the novel from the late $18^{\text {th }}$ Century ${ }^{64}$ and which underpinned the criminal justice projects of 19th Century England until the sway of social Darwinism somewhat eroded it in the latter part of the Century. In this context, we can make sense of the fact that Stevenson represents Dr. Jekyll's failure of self-control in keeping Hyde at bay as fundamentally a moral failure and not as a purely psychiatric pathology, and we can see Jekyll's emerging inability to control his translation into Hyde, or to integrate the two sides of his personality, as a cornerstone of the story's horror.

\footnotetext{
${ }^{62}$ Smith, $\mathrm{n} 10$ above, 231, 237-238.

63 cf Shapin, $n 38$ above.

${ }^{64} \mathrm{I}$ am thinking here, in particular, of the work of Jane Austen, Frances Burney, and Maria Edgeworth: see Lacey, n 4 above, 85-89.
} 


\section{THE DISAPPEARING SUBJECT ...}

Let us pause for a moment to review the argument to this point. I have suggested that the $19^{\text {th }}$ Century conception of criminal responsibility - and, by implication, conceptions of non-responsibility, epitomised by the legal conception of insanity represented a complex mix of evaluation and factual assessment; of character, and of engaged psychological capacity. At the level of legitimation, social conditions as various as the diversification of criminal law, inchoate democratisation, and the growth of the 'sciences of mind and brain' gave a new spin to conceptions of criminal responsibility as founded in the factual condition of mental, inner states of individual human beings. Similarly, at the level of co-ordination, the modernisation of criminal procedure, the growth of legal representation and hence of legal doctrines, and the rise of expert witnesses, created new resources for the investigation of the 'factual' aspects of criminal responsibility. Evaluations of character had not disappeared, but their balance with the new psychological discourse was changing. Yet - as is hardly surprising given the contested nature of the early sciences of mind and brain - there was anxiety about the robustness of the psychological model.

In this section, I consider one particular manifestation of this anxiety - and a further development which Jekyll and Hyde may help to illuminate. As Eigen has shown, the late Victorian period was marked by a curious 'new' phenomenon which found its way with increasing frequency into the criminal courts. ${ }^{65}$ This was a genre of defendants who, though not obviously displaying the classic marks of insanity such as mania, delusion, or radical cognitive dysfunction, claimed exculpation on the basis that they were - like Dr. Jekyll - mentally absent from the scene of the crime. 'Unconscious crimes' did not fall squarely within the McNaghten rules' definition of insanity as founded in cognitive failures rooted in 'disease of the mind'.66 These, rather, were failures of volition or cases of suspended consciousness which were not obviously related to disease. ${ }^{67}$

In his remarkable book analysing the social history of multiple personality, Ian Hacking traces this phenomenon back to the case of Mary Reynolds in England in 1816 and follows the development of the idea along its rise and gradual decline over the following century. ${ }^{68}$ Importantly, Hacking shows that ideas of double or multiple consciousness were not only historically, but also spatially specific (as well as being hotly contested in each time and place). ${ }^{69}$ In France, the history of dual personality remained associated with physicalist conceptions, such as hysteria, and was associated - as in the article which Stevenson's wife recalled as

\footnotetext{
65 Eigen, $\mathrm{n} 7$ above.

66 ibid, $6 \mathrm{ff}$.

67 Though of course, as Spickernell's case shows, they were sometimes nonetheless bundled within that framework: see also the cases discussed in $\mathrm{n} 8$ above.

68 Hacking, n 13 above 9; see in particular chs 9-10; Mary Reynolds is discussed on 142).

69 ibid, 134, 142.
} 
his inspiration for Jekyll and Hyde $e^{70}$ - with a dual memory as well as dissociated consciousness. In England and particularly America, the ultimate triumph of Freud's psychoanalytic theory ensured the demise of double personality by relocating 'the second self, theoretically, within the subject as repression, thus rendering the memory, in principle, as recoverable (as indeed it readily is in Stevenson's story, with acute implications for Jekyll's moral agony)..$^{71}$

Eigen has traced the genesis and disposal of cases in the criminal courts which represent the pervasive Victorian preoccupation with absent-mindedness of double consciousness - a preoccupation which realised itself in a public obsession with mesmerism, hypnosis, and sleepwalking - phenomena which find vivid literary expression not merely in the 'double consciousness/second self genre already discussed, but also in $19^{\text {th }}$ Century novels as diverse as George Eliot's Daniel Deronda, Wilkie Collins' The Moonstone, and Thomas Hardy's Tess of the d'Urbervilles. ${ }^{72}$ Such popular interest - epitomised by the mania for public displays of hypnotism - discloses a fundamental tension in Victorian society. As Eigen puts it, 'Given Victorians' well-documented preoccupation with the will and the era's paramount goal of fostering an ethic of self-mastery among all British citizens, such morbid fascination with unconscious and uncontrollable behaviour reminds one of someone with an abject fear of snakes who, upon entering a zoo, makes his way immediately for the reptile house'. ${ }^{73}$

In unravelling the causes of this preoccupation, Eigen's starting point is the assumption that knowledge and consciousness were seen as central to criminal responsibility, which took off from a Lockean notion of the unified subject as capable of being known to itself, and one whose consciousness included 'an intuitive capacity to know right from wrong'. ${ }^{74}$ It was the very threat which states of absent or multiple consciousness posed to Victorian notions of social control which underpinned the fascination with these phenomena. Focussing on examples such as sleepwalking, irresistible impulses, or unconsciousness, Eigen examines a sample of cases from the Old Bailey which posed a challenge to that model by developing '[a] vocabulary that embraced somnambulism and absence, amnesia

\footnotetext{
70 See $\mathrm{n} 15$ above.

71 ibid, 155; Mighall, n 2 above, 145; see further the competing theories discussed at n 15, 18 and 32 above.

${ }^{72}$ For a small selection of Victorian novels featuring significant incidents of absence or duality of mind, see G. Eliot, Daniel Deronda (1876, Harmondsworth: Penguin Classics, 1995) (Gwendolen Grandcourt's dissociated state implies that she is unsure whether her husband's death was an accident); W. Collins, The Moonstone (1868, Harmondsworth: Penguin Classics, 1998) (a 'theft' committed during a laudanuminduced trance); T. Hardy, Tess of the d'Urbervilles (1891, New York: Bantam Classics, 2004) (Tess's mind is 'dissociated' from her body at the time of Alec's murder, while Angel acts out some of his desires during an episode of sleepwalking); C. Brontë, Jane Eyre (1847, Harmondsworth: Penguin Classics, 2003) (Jane is able to hear Rochester's call from many miles away); W. Collins, The Woman in White (1860, Harmondsworth: Penguin Classics, 1999) (Laura Fairlie loses her identity to the 'mad' Ann Catherick); Wilde, n 32 above (Dorian Gray's dissipated life is etched onto his portrait while leaving his body and face intact). Though it is an autobiographical essay rather than a novel, mention must also be made of Thomas De Quincey's Confessions of an Opium Eater (1821, London: Signet Classics, 1966), which gives a vivid account of the experience of laudanum-induced hallucinations.

${ }^{73}$ Eigen, $\mathrm{n} 7$ above, $\mathrm{x}, 15$.

74 ibid, 117.
} 
and passion, [drawing] the courtroom defendant further away from the centuriesold conception of "the person": a consequences-perceiving, conscious and remembering being. ${ }^{75} \mathrm{He}$ finds that medical testimony was often sought in these cases and that juries not infrequently went beyond the M'Naghten rules to bring in verdicts such as 'not guilty on grounds of unconsciousness'. ${ }^{76}$

While, clearly, neither our late $20^{\text {th }}$ Century psychiatric vocabulary of 'multiple personality disorder' nor the Freudian framework of the unconscious were available to $19^{\text {th }}$ Century defendants, this did not prevent defendants like Julia Spickernell from deploying available cultural resources - notably 'the language of memory and consciousness, of horror at learning of the deed and despair at learning of one's own contribution' to distance their responsibility'. As Eigen puts it, 'Here was ample evidence that actual courtroom persons were anything but a unity: not only might they be unconscious during the crime, they could not conceive of a reason why anyone would have contemplated that action. ${ }^{77}$ From the point of view of the integrity of both criminal law's proscriptions and the legitimacy of punishment, this thought was deeply disturbing. Eigen suggests that, in the light of psychoanalytic theory,

Today's reader of the OBSP begins to wonder whether the supposed discontinuity reveals different persons, or irreconcilable emotions within the same person. Most of the crimes appear to have been premeditated, all involved victims and defendants well known to each other, and most featured the use of a lethal weapon or poison, suggesting a deliberate choice of means to effect a specific, envisioned end. ${ }^{78}$

But even this interpretation is hardly reassuring from a criminal law point of view. It is precisely this disturbing phenomenon to which Robert Louis Stevenson's 'case' of Jekyll and Hyde speaks. Like defendants relying on states of absence of mind, double consciousness, or possession by the devil, Jekyll seeks to displace not only his desires, but also his responsibility onto Hyde, whom he himself then diagnoses as suffering from 'moral insanity'. ${ }^{79}$ But the story also makes swingeing

\footnotetext{
75 ibid, 179.

76 See Elizabeth Carr's case, OBSP 1875-6, Case 413.

77 Eigen, $\mathrm{n} 7$ above; this and the quotation in the previous sentence (179). Doctrinally, these sorts of arguments led to the development of a (highly restricted) defence of automatism: the first automatism defence resulting from a plea of somnambulism did not occur until 1878, in Scotland - see Walker, n 48 above, ch 4.

${ }^{78}$ Eigen continues: "If this defendant was "missing" at the time of the crime, the perpetrator was certainly no stranger to the victim. Over the years 1843 to $1876 \ldots$..the concept of the unconscious itself... underwent the greatest change in court. Originally merely the repository of forgotten knowledge and innumerable connections among ideas, the unconscious took on a new function, storing the resentments and hostilities not expressed within the victim and the offender's day-to-day interaction'; (n 7 above, 33 34).

79 Stevenson, n 1 above, 64: 'no man morally sane could have been guilty of that crime': cf the clerk's assumption that whoever committed the Carew murder was 'mad' (29). Similarly Lanyon assumes that Jekyll is 'insane' when he receives his strange letter (49), just as he earlier inferred from Jekyll's unorthodox researches that he was 'wrong in mind'; ibid, 12.
} 
moral evaluations, many of them with strong biblical associations: Jekyll describes Hyde as 'wicked' and 'evil'; ; as 'the slime of the pit... that insurgent horror [that] was knit to him [Jekyll] closer than a wife, closer than an eye; lay caged in his flesh'. Yet when he sees his evil alter ego in the mirror, 'I was conscious of no repugnance, rather of a leap of welcome. This, too, was myself. It seemed natural and human. In my eyes it bore a livelier image, it seemed more express and single, than the imperfect and divided countenance, I had been hitherto accustomed to call mine. ${ }^{80}$

Hyde resides within Jekyll and hence represents the ultimate crisis of judgment: the unitary subject is split asunder, negating a straightforward attribution of 'factual' responsibility; that split also undermines the older discourse of evaluation of character by representing character, too, as ambivalent and as split. And the hope that new scientific knowledge - of both medical science and evolutionary biology - would provide new technologies for identifying criminality to replace the older model of character is shown, in Stevenson's horror story, to be a chimera.

This problem of grounding and legitimating attributions of responsibility within a stable human subject was not, of course, entirely new. In the era which I have characterized as that in which criminal responsibility attributions were driven by, and underpinned by a confidence in, evaluation of character, Henry Fielding was already raising questions about how it might be resolved. Of the world's judgments on Tom Jones, the likeable rogue whose criminal and dubiously lawful adventures enliven the eponymous novel, Fielding averred that ' $[a]$ single bad act no more constitutes a villain in life than a single bad part on the stage. The passions, like the managers of a playhouse, often force men upon parts without consulting their judgment, and sometimes without any regard to their talents. Thus the man, as well as the player, may condemn what he himself acts... ${ }^{81}$ and that 'few characters were so absolutely vicious as not to have the least mixture of good in them...' ${ }^{82}$ Even here, we see a forerunner of Jekyll's discovery that 'man is not truly one, but truly two', 83 and a consequent uncertainty about the grounds of moral evaluation of character. This presages a centuries-long introspection on

\footnotetext{
80 ibid, 69, 58; cf Danta, n 18 above, and discussion at n 18 above on Hyde as representing the 'animal' side of human nature - surely a Darwin-shaped theme, and one absent from the other examples of the 'double consciousness' genre which I have cited. The human/animal/evil axis is also an aspect of Bram Stoker's Dracula (1897, Oxford: Oxford University Press [Oxford World's Classics], 1998), a book which shares with Jekyll and Hyde the pitching of a fact-recording lawyer and a doctor against evil; the representation of the boundary between evil and insanity as blurred (100, ff 186); and depictions of sleepwalking $(72,86)$, hypnosis $(44)$, 'unconscious cerebration' (69), and other out of body experiences $(160,201)$. By contrast, Dracula presents its readers with a further twist to the horror of criminality's immanence in respectable urban life: that of criminality as contagious.

${ }^{81}$ H. Fielding: The History of Tom Jones, A Foundling (1749, Oxford: Oxford University Press [Oxford World's Classics], 1996), 286.,

82 ibid, 794; Fielding nonetheless continued for most of his life to place some confidence, or perhaps hope, in character as a basis for social judgment: see his 'Essay on the Knowledge of the Characters of Men' in Miscellanies, Vol 1 (H.K. Miller, ed) (1743, Oxford: Clarendon Press, 1972); see also A.F. Wilner, 'Henry Fielding and the Knowledge of Character' (1988) 18/1 Modern Language Studies 181.

${ }^{83}$ Stevenson, $\mathrm{n} 1$ above, 55.
} 
whether character is a matter of nature or nurture which also finds expression in Jekyll and Hyde: Dr. Lanyon, for example, finds himself wondering, as he looks at Hyde, not only about his 'nature and character', but also about his 'origin, his life, his fortune and status in the world'. ${ }^{84}$ In a world yet more complex and mobile than the one confronting Tom Jones' contemporaries, Hyde therefore represents a nostalgia for an earlier - perhaps mythic - world of confident moral evaluation, where 'Satan's signature upon a face' 85 is manifest as well as a deep perplexity about the implications for individual responsibility - and hence for the very project of modern governance - of the multiplicity of human subjectivity.

This sense of the crucial importance of being able to recognise criminality was of course about to realise itself in statutory form in the many late Victorian provisions classifying groups of offenders such as the 'weak-minded' and the 'inebriate'.86 And it was finding contemporary scientific expression in the statistical and photographic research of Charles' Darwin's cousin, the early eugenicist Francis Galton, who hoped (but, unsurprisingly, failed) to identify the essence of criminal personality by superimposing multiple photographic images of offenders to distil a common essence. ${ }^{87}$ Hence, perhaps, Stevenson's reversion to an older vocabulary of manifest evil: of Hyde as a 'hellish but inorganic' 'fiend'. 88 The reversion held little comfort, however, in an age which aspired to ascribe individual responsibility, yet which had begun to question the location of responsibility for 'evil'.

Equally striking was Stevenson's anticipation of Freud, not only merely in his model of split subjectivity with shared, or at least recoverable, memory, but also specifically in his observation that Jekyll's weakness of will in keeping Hyde at bay was prompted by an 'unconscious reservation' about whether he really wanted to do so. ${ }^{89}$ Decades before the widespread reception of Freud's theories, ${ }^{90}$ defendants in the criminal courts and writers like Stevenson, Wilde, Collins, and Eliot, were posing the question of responsibility for conduct beyond consciousness. It remains a puzzle that neither legal doctrine nor criminal law theory - with a few honourable exceptions, notably the pioneering work of Herbert Fingarette ${ }^{91}$ - have been keen to explore the resolution to this problem offered by Freudian theory which, in relating the subject structurally to its

\footnotetext{
84 ibid, 52.

85 ibid, 7-8, 10, 13, 16; throughout the tale, Stevenson emphasises that everyone who sees Hyde instantly recognises his evil or deformity: a clear echo of 'manifest criminality', but one which is hard to sustain in the rationalist discourse of individual responsibility, although it was about to have a new revival in the form of the criminal classifications on which the late Victorians became so keen - a development which could be read as a new twist in the history of 'external' patterns of responsibility-attribution.

${ }^{86}$ See Radzinowicz and Hood, n 60 above, chs 8-12.

87 Mighall, n 2 above, 152-154.

88 Stevenson, n 1 above, 69, 11.

${ }^{89}$ Stevenson, $\mathrm{n} 1$ above, 63.

${ }^{90}$ Freud's early work with Breuer, Studies in Hysteria, was published in 1895, while his elaborated theory of the unconscious unfolded in further publications over the next five decades.

91 H. Fingarette, Self-Deception (Berkeley: University of California Press, 1969); H. Fingarette and A. Fingarette Hasse, Mental Disability and Criminal Responsibility (Berkeley: University of California Press, 1979).
} 
unconscious, provides a framework within which one can begin to comprehend that subject's responsibility for conduct generated by its unconscious states. ${ }^{92}$ As for double consciousness, while 'multiple personality disorder' gradually established itself as an object of theoretical and clinical interest in psychiatry, psychology, and, somewhat later, philosophy, a systematic analysis of its normative and practical implications for mechanisms of responsibility-attribution in criminal law did not, as far as I am aware, appear until the publication of Elyn Saks' Jekyll on Trial in 1997.93 Whatever the explanation, Jekyll and Hyde stands for a world in transition and in crisis: juxtaposing evolutionary biology, psychological medicine, and biblical judgment; informed by modern 'science', yet deeply preoccupied by moral conventions, it leaves the reader perplexed about the proper way in which to attribute responsibility for Jekyll's imperfectly realised self-control and Hyde's manifestly criminal acts. Jekyll's disappearance and Hyde's suicide represent in other words a terrifying vision of the impossibility of an effective attribution of responsibility.

\section{CONCLUSION: HYDE'S RETURN TO THE CRIMINAL COURTS...?}

Jekyll and Hyde, then, stands as a powerful symbol of the continuing appeal of a strongly evaluative and partially character-driven practice of responsibilityattribution, even at the supposed climax of the era of 'psychologisation' of criminal responsibility. It expresses a deep anxiety about the recognisability of criminal responsibility, the distinguishability of criminality, and the very grounds for criminal judgment. It expresses the worrying thought that advances in science might be part of the problem as much as - perhaps even more than - part of the solution to these dilemmas. But what light can this late $19^{\text {th }}$ Century tale shed on principles of responsibility-attribution in the criminal process of the early $21^{\text {st }}$ Century in Britain or the USA? In particular, can the analysis which I have drawn out of Stevenson's story tell us anything about the aspects of criminalisation and punishment today which appear to mark a resurgence of character-based patterns of attribution?

Although the framework of 'character' is often thought to mark the past rather than the present of criminal justice, I am not alone in thinking that, in

\footnotetext{
92 If this can be explained by the gradual decline of defences of 'absence' or 'duality' of mind, which so preoccupied late Victorian courts, we can perhaps speculate that the issue will arise again shortly as a result of recent developments in the psychiatric understanding of multiple personality. Whether or not this is a plausible speculation, it is a topic for another paper.

${ }^{93}$ E.R. Saks and S.H. Behnke, Jekyll on Trial: Multiple Personality Disorder and Criminal Law (New York: New York University Press, 1997); on the development of 'multiple personality' in the medical sciences, psychoanalysis, philosophy, and popular culture, see also Hacking, n 13 above. Despite the title of Saks' book, Jekyll would not, strictly, come within the definition of multiple personality disorder, which typically depends on a radical failure of integration which implies separate memories: see Saks and Behnke, n 93 above, chs 1-2. See also the references to Fingarette at n 91 above; and M.S. Moore, Law and Psychiatry: Retbinking the Relationship (Cambridge: Cambridge University Press, 1984).
} 
substance if not always in form, character-based patterns of attribution appear to be experiencing something of a comeback as we move into the $21^{\text {st }}$ Century. Emerging from their subterranean (though clearly important) position in the exercise of discretion at prosecution and sentencing stages, character-based principles are enjoying a revival not only in 'three strikes and you're out' sentencing laws and paedophile registers, but also in the substantive law, particularly that dealing with terrorism, and in the operation of evidential presumptions, detention rules, and the renewed admissibility of evidence of bad character. ${ }^{94}$ Why, we might ask, has character suddenly become an acceptable explicit principle of criminalisation once again? And does this imply that its decline was more formal than real?

This paper represents a preliminary effort to piece together an interpretation of these questions. The basic thought is a simple one: If we can find traces of a character-based pattern of attribution even in the most unlikely places - such as the operation of mental incapacity offences apparently trained on the psychology of individuals in the late $19^{\text {th }}$ Century and beyond - this might be taken to suggest that the overall trajectory has been one of a shifting alignment of two alwayscoexisting principles of attribution based, respectively, on character and engaged psychological capacity, rather than (as I originally thought) the gradual displacement of one by the other. Consequently, any adequate explanatory theory of criminal responsibility will have to embrace both psychological and evaluative dimensions of the process, while attending carefully to the shifting relationship between them and to the institutional and cultural conditions which underpin those shifts.

But what does shape and underpin that shifting balance? Jekyll and Hyde can help us at least to make a start in unravelling this apparent mystery. Here is my speculative suggestion: A world which purports to give priority to capacity-based practices of responsibility-attribution - one which claims to take individuals and their engaged capacities rather than their social status or appearance seriously would be a world in which there is a strongly felt sense of the legitimation requirements posed by individual freedom, and one which enjoys some confidence

\footnotetext{
${ }^{94}$ See for example, V. Tadros, 'Justice and Terrorism' (2007) 10 New Criminal Law Review 658; L. Zedner, 'Fixing the Future: The Pre-Emptive Turn in Criminal Justice', in B. McSherry, et al (eds), Regulating Deviance: The Redirection of Criminalisation and the Futures of Criminal Law (Oxford: Hart Publishing [Onati International Series in Law and Society], 2008); M. Redmayne, 'The Relevance of Bad Character' (2002) 61 Cambridge Law Journal 684; M. Redmayne, 'The Ethics of Character Evidence' (2008) 61 Current Legal Problems 371. In the field of punishment and law enforcement, many of the developments canvassed in, for example, David Garland's The Culture of Control (Oxford: Oxford University Press, 2001) and, more recently, Jonathan Simon's Governing Through Crime (New York: Oxford University Press, 2007), as well as the rise of actuarialism charted in M. Feeley and J. Simon, 'The New Penology: Notes on the Emerging Strategy of Corrections and its Implications' (1992) 39 Criminology 449- and B. Harcourt, 'From the Ne'erDo-Well to the Criminal History Category: The Refinement of the Actuarial Model in Criminal Law' (2003) 66 Law and Contemporary Problems 99, form part of the broad development to which I want to draw attention here. I pursue the argument in greater depth in 'The Resurgence of "Character"? Responsibility in the Context of Criminalisation', in A. Duff and S. Green (eds), Philosophical Foundations of Criminal Law (forthcoming, Oxford: Oxford University Press).
} 
in its institutional capacity to deliver such individualised judgments, while maintaining adequate levels of social control. Such a world has arguably never existed, but that individualising impulse has most certainly had a significant impact on the form of (some parts of) criminal law over the course of its 'modernisation'. We might speculate that, at times when the sentiments underpinning norms towards equal liberties are fragile, perhaps because of fears about crime, or terrorism, or order more generally, explicitly character-based patterns of attribution tend to enjoy a revival. As a number of social theorists have argued, thanks to a welter of political, social, and economic conditions, this is precisely the situation we find ourselves in Britain, America, and indeed several other liberal market economies today. ${ }^{95}$

The late $19^{\text {th }}$ Century British context in which Stevenson was writing bears some striking analogies with our world today. Democracy had extended in 1884 to male householders and covered about $60 \%$ of the adult male population; yet social stratification remained the order of the day, and the 'degenerate' classes were widely seen by the 'respectable' as posing a threat to social order. But it was not only the 'degenerate classes' which threatened traditional ideas of authority and social order. There were also factors such as an economic recession which spanned the 1870s and 1880s; early intimations of the collapse of empire; and incipient troubles in Ireland in the form of Fenian activities and the struggle for Home Rule. These went alongside the perceived loosening of traditional structures of inheritance and family in an era of individual choice and the challenges to religion and tradition represented by increasingly professionalised scientific experimentation.

Science and medicine were, as they are today, ambivalent developments: on the one hand, they seemed to promise a new technology of proof and legitimation; on the other, the currency of evolutionary theory and early medical science was perceived as threatening individual responsibility - prompting one reviewer to complain that Stevenson's story added to this culture by 'reducing individual freedom to zero, weakening the sense of responsibility'. ${ }^{96}$ (Clues to the resultant social anxieties are Jekyll's more traditional medical colleague's deep suspicion of the course of his chemical research, and his lawyer's horror at his will, which leaves all his property to the unknown Hyde. ${ }^{97}$ ) Science at once threatened the established order and promised resources for recreating a new form of 'manifest criminality' through the methods designed to identify criminal character - a development which would of course echo through the criminology of the early $20^{\text {th }}$ Century, giving a new spin to the construction of 'external' patterns of responsibility-attribution. In the end, the capacity principle gained a serious foothold in the law governing the more serious criminal offences, displacing

\footnotetext{
${ }^{95}$ See for example, Garland, n 94 above; J. Young, The Exclusive Society (London: Sage, 1999); N. Lacey, The Prisoners' Dilemma: Political Economy and Punishment in Contemporary Societies (Cambridge: Cambridge University Press, 2008).

${ }^{96} \mathrm{~J}$.A. Symonds, quoted in Mighall, n 2 above, 145.

${ }^{97}$ Stevenson, n 1 above, 12, 18.
} 
explicit character attribution onto the less visible areas of the prosecution and sentencing processes. Meanwhile, technologies geared to the identification of criminals - from professional detective work and policing through Lombrosian criminology and statistics to contemporary offender profiling - multiplied, in a succession of developments which have walked a curiously separate track from the criminal law's professed commitment to establishing responsibility by investigating whether a defendant's psychological capacities were properly engaged at the time of her offence.

The revival of 'character' in contemporary criminal justice might be seen as the criminal law manifestation, in short, of what David Garland has called 'the culture of control': a reverberation of anxiety in a world marked by renewed economic and social insecurity and one in which some countries have manifested an impulse to ever greater criminalisation and penal harshness: 'governing through crime' and 'overcriminalisation', in the words of Jonathan Simon's and Douglas Husak's recent contributions to the analysis of these worrying social developments. ${ }^{98}$ In our world, as in Stevenson's, the burgeoning of theory and practice in the sciences - notably in the fields of psychiatry, psychology, and psychoanalysis - has done little to address the resultant moral and political uncertainties. As Elyn Saks' review of the scholarship on multiple personality disorder and its implications for criminal law reminds us, even if we were to assume the validity of the clinical category of multiple personality, we are left with a number of intractable moral and practical questions - of which the justice of punishing 'innocent' person-like doubles is only the most vivid. ${ }^{99}$ In standing for the duality of not only human identity, but also criminal judgment, Jekyll and Hyde suggests that the development of responsibility-attribution is not a linear trajectory from status to contract, from manifest to subjective criminality, from character to choice and capacity. Rather, it is a complex and shifting alignment of apparently competing principles, which coalesce, more or less successfully, to legitimate and co-ordinate criminal judgment under specific social conditions. Only when we understand the conditions which underpin the relative influence of these principles will we be in a position to address the further challenge of how to resist the resurgence of character-based mechanisms which foster the most dangerous aspects of criminalisation and punishment as forms of social power.

${ }^{98}$ Simon, n 94 above; D. Husak, Overcriminalization (Oxford: Oxford University Press, 2008).

${ }^{99}$ Saks and Behnke, n 93 above, ch 5. 